\title{
Gadolinium enhances the sensitivity of SW-1573 cells for thermal neutron irradiation
}

\author{
N.A.P. FRANKEN ${ }^{1}$, J.W.J. BERGS ${ }^{1}$, T.T. KOK ${ }^{1}$, R.R.N. KUPERUS ${ }^{2}$, \\ F. STECHER-RASMUSSEN ${ }^{2}$, J. HAVEMAN ${ }^{1}$, C. VAN BREE ${ }^{1}$ and L.J.A. STALPERS ${ }^{1}$ \\ ${ }^{1}$ Laboratory of Experimental Oncology and Radiobiology (LEXOR), Department of Radiotherapy, Academic Medical Centre, \\ University of Amsterdam, P.O. Box 22700, 1100 DE Amsterdam; ${ }^{2}$ Nuclear Research Group, Petten, The Netherlands
}

Received August 19, 2005; Accepted October 26, 2005

\begin{abstract}
Gadolinium neutron capture therapy (Gd-NCT) is an experimental cancer treatment based on the physical principal that neutron capture by gadolinium-157 ensures the release of focal high-dose radiation, such as $\gamma$-rays and electrons. Survival and induction of chromosomal aberrations of human SW-1573 cells was studied after thermal neutron irradiation without and with gadolinium. After neutron irradiation with Gd-DTPA, an $\alpha$-enhancement factor of 2.3 was obtained compared to thermal neutron irradiation alone. Gd-DTPA could not radioenhance the cells for $\gamma$-ray irradiation. Induction of colour junctions and chromosome fragments by thermal neutron irradiation and Gd-NCT were studied using PCC-FISH. Correlations ( $\mathrm{r}^{2}$-value) between survival and chromosome aberrations ranged from 0.81 to 0.94 for colour junctions and from 0.78 to 0.98 for chromosome fragments of chromosomes 18 and 2 respectively. Thermal neutron irradiation with or without gadolinium induced more chromosome aberrations than $\gamma$-ray irradiation. After correction for chromosome length it appeared that both chromosomes were equally sensitive to radiation. It is concluded that Gd-NCT at a non-toxic concentration of gadolinium is effective in inducing cell death and chromosome aberrations in in vitro cell cultures.
\end{abstract}

\section{Introduction}

Gadolinium-neutron capture therapy (Gd-NCT) is an experimental cancer treatment modality which utilizes the gadolinium neutron capture reaction after irradiation with thermal neutrons. Gadolinium-157 (Gd-157) has some advantages over boron-10 in NCT because the neutron

Correspondence to: Dr N.A.P. Franken, Academic Medical Center, University of Amsterdam, Laboratory of Experimental Oncology and Radiobiology (LEXOR), Department of Radiotherapy, Rm F0-205, P.O. Box 22700, 1100 DE Amsterdam, The Netherlands

E-mail: N.A.Franken@amc.uva.nl

Key words: gadolinium, thermal neutron irradiation, chromosome aberrations: colour junctions and fragments capture cross section is 66 times larger. Moreover, when ${ }^{157} \mathrm{Gd}$ is irradiated with thermal neutrons, it emits long-range $\gamma$-rays, internal conversion electrons, X-rays and Auger electrons (1). Based on these properties, it has been suggested that Gd-NCT has an important potential for cancer therapy (2-4).

Radiation damage in mammalian cells leads to cell reproductive death caused by chromosomal damage. It is expected that most of the damage induced by thermal neutron irradiation with or without gadolinium is high-LET radiation damage (5). Ward et al (6) suggested that high-LET radiation produces more complex DNA lesions which are less easily repaired than low-LET irradiation. Several studies have indeed shown that high-LET irradiation produced more residual chromosome breaks than low-LET irradiation. Löbrich et al (7), using pulsed-field gel electrophoresis, found that the repair kinetics was generally slower after irradiation with high-LET particles as compared to X-irradiation and that a larger proportion of the breaks remained unrepaired after $24 \mathrm{~h}$. Wu et al (8) using PCC-FISH demonstrated that the frequency of chromosome fragments was higher after highLET radiation than after low-LET radiation and that the ratio of chromosome fragments increased steadily with LET up to a peak of $440 \mathrm{keV} / \mu \mathrm{m}$.

As gadolinium-DTPA (Magnevist ${ }^{\circledR}$ ) is already applied in clinical practice in MRI diagnostics, it is of interest to study the possible advantages of this Gd-compound combined with neutron irradiation. We have carried out survival and chromosome aberration induction studies after Gd-NCT in order to provide insights in the mechanism of this treatment. The outcome of these studies is compared with survival and induction of chromosomal aberrations after $\gamma$-rays.

\section{Materials and methods}

Cell culture. Human SW-1573 cells (squamous lung carcinoma) were grown at $37^{\circ} \mathrm{C}$ as monolayers in $75-\mathrm{cm}^{2}$ tissue culture flasks (Costar) in Leibowitz-15 medium (L-15, Gibco-BRL) supplemented with $10 \%$ fetal bovine serum and $2 \mathrm{mM}$ glutamine. The L-15 medium does not require a $\mathrm{CO}_{2}$ atmosphere in incubation. The doubling time of the cells during exponential growth is $22-24 \mathrm{~h}(9,10)$. For experiments, the cells were incubated for $3 \mathrm{~h}$ in medium containing 0 or $2.5 \mathrm{mM}$ of gadolinium-DTPA (Magnevist ${ }^{\circledR}$ ). 
Gadolinium-DTPA. In Gd-DTPA (dimeglumingadopentate, Magnevist ${ }^{\circledR}$, Schering AG, Germany), gadolinium is bound to the sugar-like molecule diethylenetraminipentaacetic acid. Magnevist ${ }^{\circledR}$ is known to target brain gliomas because of the blood-brain-barrier disruption in these tumours. The pharmacokinetics, bio distribution and tolerance of Gd-DTPA are welldocumented $(11,12)$.

The Gd-DTPA in all experiments was diluted to $2.5 \mathrm{mM}$ (from the $500 \mathrm{mM}$ Gd-DTPA in Magnevist ${ }^{\circledR}$ ). The natural abundance of ${ }^{157} \mathrm{Gd}$ is $15.7 \%$ so a concentration of $2.5 \mathrm{mM}$ Gd-DTPA equals $2.5 \times 0.157=0.39 \mathrm{mM}{ }^{157} \mathrm{Gd}$.

Irradiation. Cells were irradiated in suspensions (medium with $2.5 \mathrm{mM}$ Gd-DTPA) in Eppendorf tubes. Gadolinium neutron capture therapy (Gd-NCT) was performed at the low flux reactor (LFR) of the nuclear reaction group at Petten with thermal neutrons produced in the low flux reactor. Cells were irradiated with $0,0.313,0.625$ and 1.25 Gy at a dose rate of $1.25 \mathrm{~Gy} / \mathrm{h} . \gamma$-Ray irradiation was performed with a ${ }^{137} \mathrm{Cs}$-source yielding a dose rate of about $0.8 \mathrm{~Gy} / \mathrm{min}$ with doses of up to $8 \mathrm{~Gy}$.

Cell survival. Two hours after irradiation (after returning from the LFR at Petten), cells were plated at appropriate cell numbers for clonogenic assay. Ten days after plating, the colonies were fixed in $6 \%$ glutaraldehyde and stained with $0.05 \%$ crystalviolet. Colonies of 50 cells or more were scored as originating from a single clonogenic cell. The plating efficiency of these cells is $85 \pm 5 \%$. Cell survival curves were analysed using SPSS statitistical software by means of a fit of the data by multiple regression according to the LQ formula: $S(D) / S(0)=\exp -\left(\alpha D+\beta D^{2}\right)(13)$. Differences between survival curves with and without gadolinium were tested for significance using SPSS. The $\alpha$-enhancement ratio was calculated by dividing the $\alpha$-value of the survival curve after Gd-NCT with the $\alpha$-value of the survival curve after thermal neutron irradiation alone.

Scoring of aberrations and fluorescence in situ hybridization. In separate experiments, cells were treated to prepare prematurely condensed chromosome slides (PCCs). After irradiation, the cells were plated in culture dishes. On the following day the monolayer cultures of cells were treated with calyculine A for one hour to induce PCC formation (14). Then, the cells were harvested, treated with hypotonic $\mathrm{KCl}$ solution $(0.075 \mathrm{M})$ for $20 \mathrm{~min}$ and fixed in methanol/ acetic acid (3:1). Finally, the cell suspension was dropped on precleaned slides and air-dried. PCC spreads were hybridized to whole chromosome-specific FITC and Cy-3 labelled probes of chromosome 2 and 18 (Cambio UK) using the method described by Darroudi et al (15). Slides were counterstained with DAPI $(2.5 \mu \mathrm{g} / \mathrm{ml})$ and embedded in antifade solution (Vecta shield, Vector laboratories, Burlingame, CA).

SW-1573 cells contain between 60 and 67 chromosomes. To study the relationship between yield of exchanges and radiation doses, chromosomes 2 and 18 were selected (16). These chromosomes exhibited no spontaneous exchanges. Two copies of chromosome 18 and three copies of chromosome 2 were present in over $95 \%$ of the metaphases studied. According to the chromosome length measurements, the

\section{Thermal Neutron irradiation}
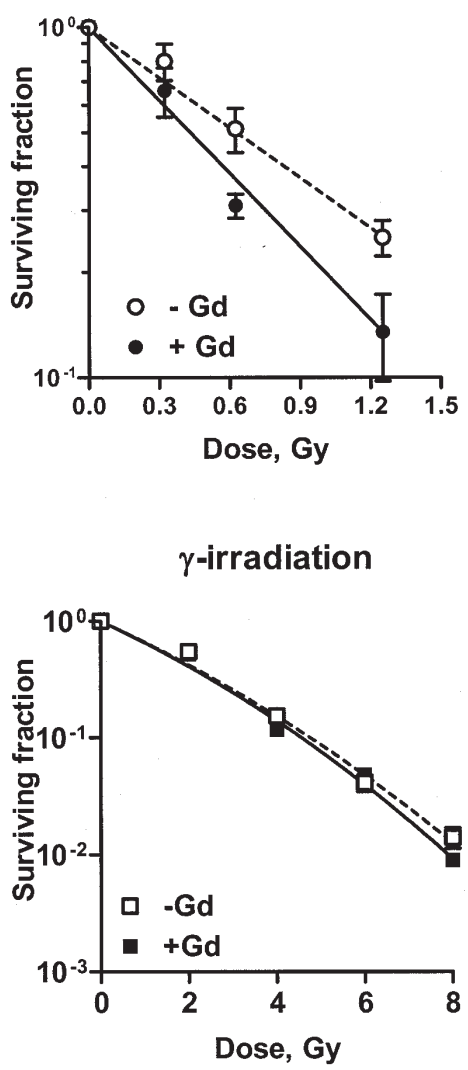

Figure 1. Survival curves after thermal neutron irradiation (top) and $\gamma$-ray irradiation (bottom) after incubation of the cells with or without $2.5 \mathrm{mM} \mathrm{Gd-}$ DTPA. After Gd-NCT an $\alpha$-enhancement ratio of 2.3 is obtained. The values for the LQ parameters are: $\alpha=0.88 \pm 0.17, \alpha=1.86 \pm 0.32$ for thermal neutron irradiation only and Gd-NCT respectively and $\alpha=0.29 \pm 0.04$ and $\beta=0.031 \pm 0.007, \alpha=0.30 \pm 0.04$ and $\beta=0.032 \pm 0.007, \gamma$-rays only and $\gamma$-rays $+\mathrm{Gd}$, respectively (for thermal neutron survival curves no $\beta$-value could be calculated).

relative lengths of chromosomes 18 and 2 were $3.6 \pm 0.3 \%$ and $7.8 \pm 0.6 \%$ of the complete genome, respectively (17). Slides were examined using a fluorescence microscope (Zeiss Axioskop 2 MOT) equipped with a triple filter block to detect all painted chromosomes (FITC, Cy-3 and DAPI for total DNA) in one image. Two- to four-hundred PCCs were scored for each dose and chromosome. The induction of colour junctions and chromosome fragments of painted chromosomes was scored according to the method described by Tucker et al (18). An exchange between a fragment of a painted chromosome and a fragment of an unpainted chromosome was scored as a colour junction. The rejoining of two identically painted chromosome fragments without a centromer was scored as fragment.

\section{Results}

In Fig. 1 the survival curves are presented after thermal neutron irradiation and $\gamma$-ray irradiation after incubation of the cells with or without $2.5 \mathrm{mM}$ Gd-DTPA. It is obvious that GdDTPA enhances the effects on cells of irradiation with thermal neutrons but not with $\gamma$-rays. The $\alpha$-enhancement 
Table I. Frequency of colour junctions in chromosomes 2 and 18 after irradiation with thermal neutrons and $\gamma$-rays of SW-1573 lung tumour cells with or without gadolinium.

\begin{tabular}{|c|c|c|c|c|c|c|c|c|}
\hline \multirow[b]{3}{*}{ Dose (Gy) } & \multicolumn{4}{|c|}{$\begin{array}{l}\text { Thermal neutron irradiation } \\
\text { Colour junctions } / 200 \text { cells }\end{array}$} & \multicolumn{4}{|c|}{$\begin{array}{c}\gamma \text {-Irradiation } \\
\text { Colour junctions/200 cells }\end{array}$} \\
\hline & \multicolumn{2}{|c|}{ Chromosome 2} & \multicolumn{2}{|c|}{ Chromosome 18} & \multicolumn{2}{|c|}{ Chromosome 2} & \multicolumn{2}{|c|}{ Chromosome 18} \\
\hline & $-\mathrm{Gd}$ & $+\mathrm{Gd}$ & $-\mathrm{Gd}$ & $+\mathrm{Gd}$ & $-G d$ & $+\mathrm{Gd}$ & $-G d$ & $+\mathrm{Gd}$ \\
\hline 0.0 & $3.5 \pm 1.6$ & 0 & $2.0 \pm 0.9$ & 0 & 0 & $2.0 \pm 1.0$ & $1.6 \pm 0.8$ & $0.7 \pm 0.4$ \\
\hline 0.3 & $12.5 \pm 2.1$ & $20.0 \pm 3.8$ & $6.0 \pm 0.9$ & $9.0 \pm 3.3$ & & & & \\
\hline 0.6 & $28.0 \pm 5.7$ & $32.0 \pm 7.5$ & $7.5 \pm 0.3$ & $17.5 \pm 1.2$ & & & & \\
\hline 1.2 & $42.0 \pm 8.5$ & $49.0 \pm 8.9$ & $12.0 \pm 3$ & $12.0 \pm 4.0$ & & & & \\
\hline 2.0 & & & & & $7.1 \pm 2.4$ & $10.5 \pm 3.5$ & $5.4 \pm 1.8$ & $1.6 \pm 0.8$ \\
\hline 4.0 & & & & & $11.8 \pm 3.9$ & $11.4 \pm 3.8$ & $8.8 \pm 2.9$ & $8.5 \pm 2.8$ \\
\hline
\end{tabular}

Table II. Frequency of chromosome fragments in chromosomes 2 and 18 after irradiation with thermal neutrons and $\gamma$-rays of SW-1573 lung tumour cells with or without gadolinium.

\begin{tabular}{|c|c|c|c|c|c|c|c|c|}
\hline \multirow[b]{3}{*}{ Dose (Gy) } & \multicolumn{4}{|c|}{$\begin{array}{l}\text { Thermal neutron irradiation } \\
\text { Chromosome fragments/200 cells }\end{array}$} & \multicolumn{4}{|c|}{$\begin{array}{c}\gamma \text {-Irradiation } \\
\text { Chromosome fragments } / 200 \text { cells }\end{array}$} \\
\hline & \multicolumn{2}{|c|}{ Chromosome 2} & \multicolumn{2}{|c|}{ Chromosome 18} & \multicolumn{2}{|c|}{ Chromosome 2} & \multicolumn{2}{|c|}{ Chromosome 18} \\
\hline & $-G d$ & $+\mathrm{Gd}$ & $-G d$ & $+\mathrm{Gd}$ & $-G d$ & $+\mathrm{Gd}$ & $-\mathrm{Gd}$ & $+\mathrm{Gd}$ \\
\hline 0.0 & $3.0 \pm 1.4$ & 0 & $2.0 \pm 0.9$ & 0 & 0 & $2.0 \pm 1.0$ & 0 & $1.6 \pm 0.8$ \\
\hline 0.3 & $15.5 \pm 5.4$ & $39.5 \pm 2.2$ & $5.0 \pm 0.5$ & $11.0 \pm 2.4$ & & & & \\
\hline 0.6 & $30.5 \pm 3.1$ & $58 \pm 4.7$ & $14.0 \pm 4.7$ & $21.0 \pm 3.3$ & & & & \\
\hline 1.2 & $56.0 \pm 5.7$ & $77.5 \pm 6.4$ & $48.0 \pm 5.0$ & $44.0 \pm 4.5$ & & & & \\
\hline 2.0 & & & & & $21.2 \pm 7.1$ & $10.5 \pm 3.5$ & $7.1 \pm 2.4$ & $3.4 \pm 1.3$ \\
\hline 4.0 & & & & & $35.8 \pm 11.8$ & $56.0 \pm 18.7$ & $8.8 \pm 2.9$ & $15.7 \pm 5.2$ \\
\hline
\end{tabular}

ratio of the survival curve after Gd-NCT as compared to thermal neutron irradiation alone was 2.3 (the LQ parameters are listed in the legend of Fig. 1). The difference between the survival curves after NCT with and without gadolinium is significant $(\mathrm{p}=0.002)$.

In Tables I and II, the number of colour junctions and chromosome fragments of chromosomes 2 and 18 is presented after thermal neutron irradiation or $\gamma$-rays with or without incubation of the cells with Gd-DTPA. After Gd-NCT, the number of colour junctions and chromosome fragments is increased as compared to thermal neutron irradiation alone. The differences are not statistically significant. The numbers of chromosomal aberrations found after $\gamma$-rays with and without Gd are similar. After $\gamma$-rays, lower numbers of colour junctions and chromosome fragments were found than after thermal neutron irradiation with or without gadolinium.

Fig. 2 shows the linear regression analyses between the surviving fraction and induction of chromosome aberrations after thermal neutron irradiation and $\gamma$-rays with and without gadolinium. Similar correlations between surviving fraction and colour junctions or chromosome fragments after thermal neutron irradiation with and without Gd were obtained for each chromosome. Therefore, the data for thermal neutron irradiation and Gd-NCT were pooled for the overall linear regression analysis. However, there are differences in these correlations between chromosomes: for colour junctions $r^{2}=0.98$ and $r^{2}=0.78$ and for chromosome fragments $r^{2}=0.94$ and $\mathrm{r}^{2}=0.81$ for chromosomes 2 and 18 respectively. Also for $\gamma$-rays, good correlations between surviving fractions and colour junctions or chromosome fragments were obtained (Fig. 3). $\mathrm{r}^{2}$-Values, for colour junctions, were 0.87 and 0.82 and, for fragments, were 0.81 and 0.76 for chromosomes 2 and 18 respectively. Chromosome 2 shows more aberrations after irradiation than chromosome 18 (Table I). However, after correction for chromosome length, chromosome 18 being 2.2 times shorter than chromosome 2 , it is calculated that the difference in number of aberrations between the chromosomes after thermal neutron or $\gamma$-ray irradiation is not significant.

\section{Discussion}

This study shows that NCT with gadolinium resulted in a clear radio enhancement as compared with thermal neutron irradiation without gadolinium. This is obvious from the 

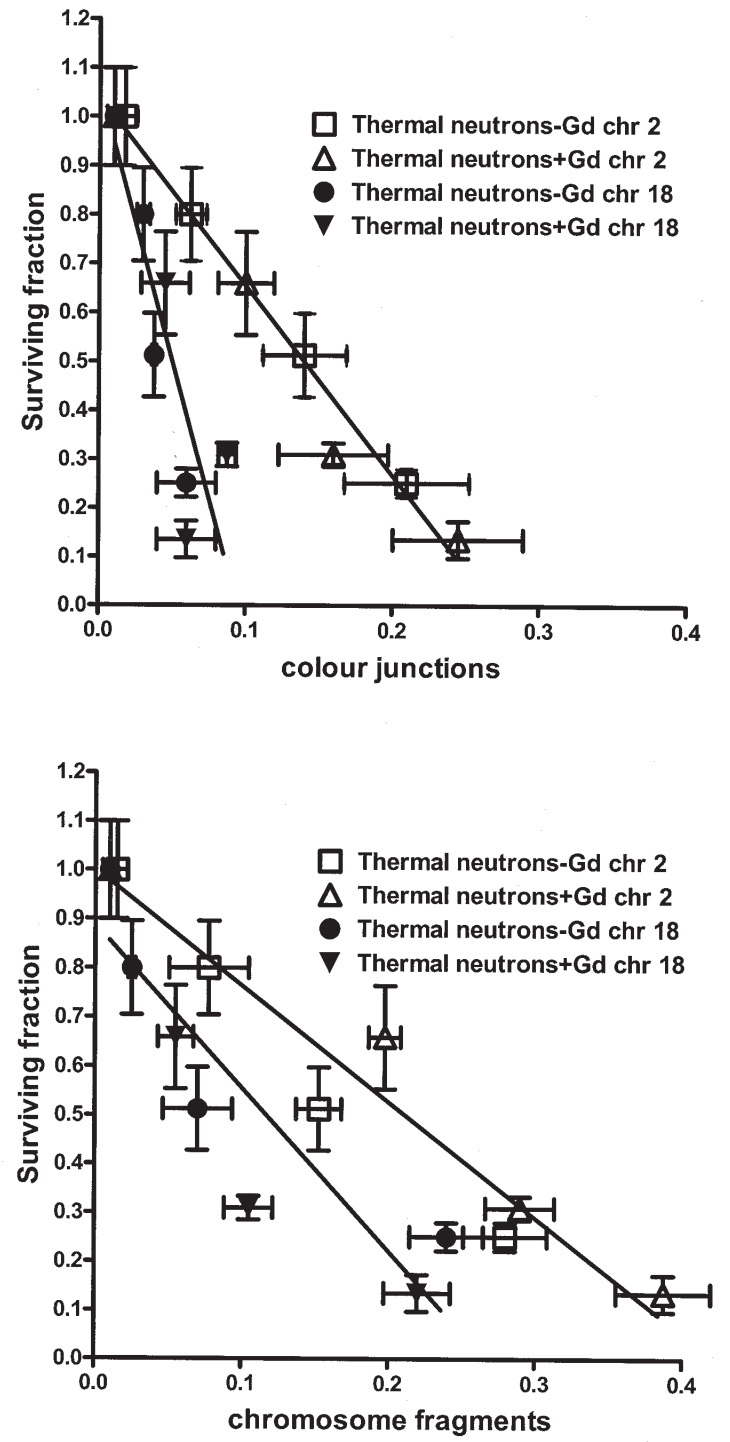

Figure 2. Linear regression analyses between the surviving fraction and frequency of colour junctions (top); and between the surviving fraction and frequency of chromosome fragments (bottom), after thermal neutron irradiation with or without gadolinium.

value of 2.3 for the $\alpha$-enhancement ratio obtained for cell survival. Also, the induction of chromosomal aberrations after Gd-NCT is higher than after thermal neutron irradiation alone. The increase of radiation effects produced by $\mathrm{Gd}$ is probably due to extra conversion electrons and photons. The contribution of high-LET Auger electrons is disputable. De Stasio et al (19) observed some intracellular accumulation after long exposure to a high dose $(25 \mathrm{mg} / \mathrm{ml}, 120 \mathrm{~h})$ of GdDTPA. In our experiments, it is assumed that cells hardly take-up Gd-DTPA as, after a 3-h incubation with $2.5 \mathrm{mM}$, no toxicity was measured. Therefore, the Gd-DTPA will be too far from the nucleus to produce Auger electron-induced DNA damage.

It was found that the survival curve after thermal neutron irradiation with and without gadolinium showed no initial shoulder. This is in agreement with the results of Maki et al (5) who studied the survival of Hela cells after thermal neutron irradiation alone. There are several papers describing the DNA damaging effects of thermal neutron irradiation with or without
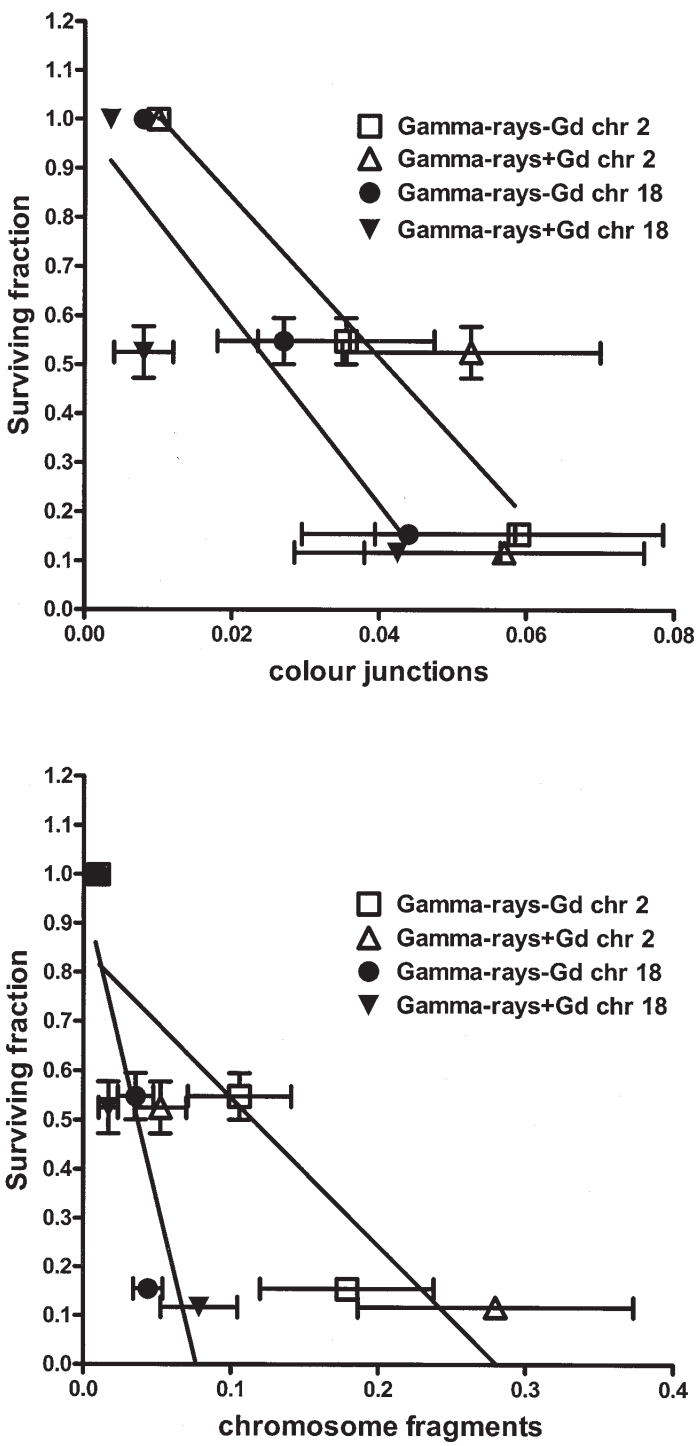

Figure 3. Linear regression analyses between the surviving fraction and frequency of colour junctions (top); and between the surviving fraction and frequency of chromosome fragments (bottom), after $\gamma$-irradiation with or without gadolinium.

boron or gadolinium (5,20-22). Martin et al $(20,21)$ observed DNA-dsbs after treating test-tube DNA by Gd-NCT. Because, in this study, the Gd was in close proximity to the DNA, the Auger electrons were held responsible for this effect. Maki et al (5) examined the effects on cellular viability and induction and repair kinetics of DNA strand breaks in HeLa cells after exposure to a thermal neutron beam and compared them with those after $\gamma$-irradiation. No difference in the repair kinetics of DNA-ssb and DNA-dsb was observed between thermal neutrons and $\gamma$-rays. This is in contrast with the findings of Pöller et al (22) who found a significantly reduced DNA repair capacity after boron-NCT or thermal neutron irradiation alone as compared with X-irradiation. Our study shows that thermal neutron irradiation is more effective in producing chromosomal damage than $\gamma$-ray irradiation as more colour junctions and fragments were produced after lower doses.

In the human tumor cell line, SW-1573, a higher number of fragments was found after both thermal neutron irradation and $\gamma$-rays as compared to the numbers of unrejoined chromosomes 
found by Wu et al (8) in normal human fibroblasts, AG-1522 cells. Wu et al (8) exposed the AG-1522 cells to $\gamma$-rays and high LET ion particles and observed an increase in the frequency of unrejoined chromosomes after high-LET radiation as compared to low-LET radiation. The findings are dependent on the cell line. Bergs et al (23) found similar numbers of fragments in the SW-1573 cells after $\gamma$-ray irradiation. The difference between number of fragments and unrejoined chromosomes can also be due to the state of the cells during irradiation and the repair time allowed after irradiation. Wu et al (8) irradiated the cells in a confluent state and allowed the cells to repair for $24 \mathrm{~h}$ and then the cells were transferred from a T-25 flask to T-75 culture flask for a further $32-\mathrm{h}$ incubation at $37^{\circ} \mathrm{C}$ before calyculin $\mathrm{A}$ was added to make PCCs. The AG-1522 cells may have been induced into cell division and cells with unrejoined chromosomes may not have survived mitosis. In our experiments, the SW-1573 cells were irradiated in suspension and then transferred to culture disks and allowed to attach and, $16 \mathrm{~h}$ later, PCCs were performed by adding calyculin A. It is very unlikely that the SW-1573 cells went into mitosis in this period and cells with fragment chromosomes were still part of the population.

Correlations between surviving fractions and chromosomal aberrations (colour junctions or fragments) showed that they were very similar for Gd-NCT and thermal neutron irradiation without gadolinium and also for $\gamma$-rays with or without gadolinium. In a previous study, we compared the effects of low-LET irradiation with and without BrdUrd or IdUrd (24-27) and observed a good correlation between survival and chromosome aberrations. Our results indicate that gadolinium contributes to the cell killing effect of thermal neutrons but not of $\gamma$-rays. To our knowledge, this is the first study in which induction of DNA damage by Gd-NCT is examined at the chromosomal level and where survival is correlated with this damage. Gd-DTPA is a promising compound for use in NCT. However, it remains to be established whether Gd-NCT will be an adequate radiation treatment for cancer.

\section{Acknowledgements}

We wish to thank Ing. R. Ten Cate for technical help with the FISH slides. This work is supported by the Interuniversity Research Institute of Radiopathology Radiation Protection, J.A. Cohen Institute (IRS project no: 7.1.7.). The Maurits and Anna de Kock foundation is acknowledged for providing laboratory equipment.

\section{References}

1. Greenwood RC, Reich CW, Baader HA, Breitig D, Schult OWB, Fogelberg B, Franklin A, Mampe W, von Egidy T and Schreckenbach K: Collective and two-quasiparticle states in ${ }^{158} \mathrm{Gd}$ observed through study of radiative ${ }^{157} \mathrm{Gd}$. Nuclear Physics A 304: 327-428, 1978.

2. Stalpers LJA, Kuipers S, Vroegindewij C, Slotman BJ and Stecher-Rasmussen F: Towards gadolinium neutron capture therapy. Proceedings of the 9th International Symposium on Neutron Capture Therapy for Cancer, Kyoto University, Osaka. pp227-228, 2000.

3. Stalpers LJA, van Vliet-Vroegindewij C, Stecher-Rasmussen F and Slotman BJ: Gadolinium neutron capture therapy (GdNCT): treatment planning versus conventional radiotherapy. Radiother Oncol 56: S80, 2000
4. Stalpers LJA, Stecher-Rasmussen F, Kok T, Boes J, van VlietVroegindewij C, Slotman BJ and Haveman J: Radiobiology of neutron capture therapy. In: Research and Development in Neutron Capture Therapy. Sauerwein W, Moss R and Wittig A (eds). Essen, Germany Monduzzi Editore, pp825-829, 2002.

5. Maki H, Saito M, Koabayashi T, Kawai K and Akaboshi M: Cell inactivation and DNA single- and double-strand breaks in cultured mammalian cells irradiated by a thermal neutron beam. Int J Radiat Biol 50: 795-809, 1986.

6. Ward JF: Biochemistry of DNA lesions. Radiat Res 8: S103-S111, 1985.

7. Lobrich M, Cooper PK and Rydberg B: Joining of correct and incorrect DNA ends at double-strand breaks produced by highlinear energy transfer radiation in human fibroblasts. Radiat Res 150: 619-626, 1998

8. Wu H, Furusawa Y, George K, Kawata T and Cucinotta FA: Analysis of unrejoined chromosomal breakage in human fibroblast cells exposed to low- and high-LET radiation. J Radiat Res (suppl 43): S181-S185, 2002.

9. Franken NAP, van Bree C, Streefkerk JO, Kuper IMJA, Rodermond HM, Kipp JBA, Haveman J and Barendsen GW: Radiosensitization by iodo-deoxyuridine in cultured SW-1573 human lung tumor cells: effects on alpha and beta of the linearquadratic model. Oncol Rep 4: 1073-1076, 1997.

10. Franken NAP, van Bree C, Veltmaat MAT, Rodermond HM, Haveman J and Barendsen GW: Radiosensitization by bromodeoxyuridine and hyperthermia: analysis of linear and quadratic parameters of radiation survival curves of two human tumor cell lines. J Radiat Res 42: 179-190, 2001.

11. Weinmann HJ, Brasch RC, Press WR and Wesbey GE: Characteristics of gadolinium-DTPA complex: a potential NMR contrast agent. Am J Roentgenol 142: 619-624, 1984.

12. Yoshida K, Furuse M, Kaneoke Y, Saso K, Inao S, Motegi Y, Ichihara K and Izawa A: Assessment of T1 time course changes and tissue-blood ratios after Gd-DTPA administration in brain tumors. Magn Reson Imaging 7: 9-15, 1989.

13. Barendsen GW: Parameters of linear-quadratic radiation doseeffect relationships: dependence on LET and mechanisms of reproductive cell death. Int J Radiat Biol 71: 649-655, 1997.

14. Bezrookove V, Smits R, Moeslein G, Fodde R, Tanke HJ, Raap AK and Darroudi F: Premature chromosome condensation revisited: a novel chemical approach permits efficient cytogenetic analysis of cancers. Genes Chromosomes Cancer 38: 177-186, 2003.

15. Darroudi F, Fomina J, Meijers M and Natarajan AT: Kinetics of the formation of chromosome aberrations in X-irradiated human lymphocytes, using PCC and FISH. Mutat Res 404: 55-65, 1998.

16. Castro Kreder NC, van Bree C, Franken NAP and Haveman J: Effects of gemcitabine on cell survival and chromosome aberrations after pulsed low dose-rate irradiation. J Radiat Res 45: 111-118, 2004.

17. Castro Kreder NC, van Bree C, Franken NAP and Haveman J: Chromosome aberrations detected by FISH and correlation with cell survival after irradiation at various dose-rates and after bromodeoxyuridine radiosensitization. Int J Radiat Biol 78: 203-210, 2002.

18. Tucker JD, Morgan WF, Awa AA, Bauchinger M, Blakey D, Cornforth MN, Littlefield LG, Natarajan AT and Shasserre C: A proposed system for scoring structural-aberrations detected by chromosome painting. Cytogen Cell Genet 68: 211-221, 1995

19. De Stasio G, Casalbore P, Pallini R, Gilbert B, Sanita F, Ciotti MT, Rosi G, Festinesi A, Larocca LM, Rinelli A, Perret D, Mogk DW, Perfetti P, Mehta MP and Mercanti D: Gadolinium in human glioblastoma cells for gadolinium neutron capture therapy. Cancer Res 61: 4272-4277, 2001.

20. Martin RF, D'Cunha G, Pardee M and Allen BJ: Induction of DNA double-strand breaks by $157 \mathrm{Gd}$ neutron capture. Pigment Cell Res 2: 330-332, 1989.

21. Martin RF, D'Cunha G, Pardee M and Allen BJ: Induction of double-strand breaks following neutron capture by DNA-bound 157Gd. Int J Radiat Biol 54: 205-208, 1988.

22. Poller F, Bauch T, Sauerwein W, Bocker W, Wittig A and Streffer C: Comet assay study of DNA damage and repair of tumour cells following boron neutron capture irradiation with fast d(14)+Be neutrons. Int J Radiat Biol 70: 593-602, 1996.

23. Bergs JWJ, Franken NAP, ten Cate R, van Bree C and Haveman J: Effects of cisplatin and $\gamma$-irradiation on cell survival, the induction of chromosomal aberrations and apoptosis in SW-1573 cells. Mutat Res (In press). 
24. Franken NAP, van Bree C, Kipp JBA, Rodermond HM, Haveman $J$ and Barendsen GW: BrdUrd-induced radiosensitization of two human tumour cell lines at iso-levels of incorporation. Oncol Rep 7: 937-940, 2000.

25. Franken NAP, Ruurs P, Ludwikow G, van Bree C, Kipp JBA, Darroudi F and Barendsen GW: Correlation between cell reproductive death and chromosome aberrations assessed by FISH for low and high doses of radiation and sensitization by iododeoxyuridine in human SW-1573 cells. Int J Radiat Biol 75: 293-299, 1999.

26. Franken NAP, VanBree C, Kipp JBA and Barendsen GW: Modification of potentially lethal damage in irradiated Chinese hamster V79 cells after incorporation of halogenated pyrimidines. Int J Radiat Biol 72: 101-109, 1997.

27. Franken NAP, Van Bree C, Veltmaat MAT, Ludwikow G, Kipp JBA and Barendsen GW: Increased chromosome exchange frequencies in iodo-deoxyuridine-sensitized human SW-1573 cells after gamma-irradiation. Oncol Rep 6: 59-63, 1999. 